\title{
ANALISIS RASIO LIKUIDITAS DAN RASIO PROFITABILITAS PADA PT. MATAHARI DEPARTMENT STORE TBK \& PT. RAMAYANA LESTARI SENTOSA TBK
}

\author{
M. Astri Yulidar ${ }^{1}$, Devi Putri Milanda ${ }^{2}$, Dede Lawitan ${ }^{3}$, Kadek Riska D. A. ${ }^{4}$, \\ Flora Anggret ${ }^{5}$ \\ threejulie@gmail.com
}

\author{
${ }^{12}$ Dosen Fakultas Ekonomi Program Studi Akuntansi UWGM Samarinda \\ ${ }^{345}$ Mahasiswa Fakultas Ekonomi Program Studi Akuntansi UWGM Samarinda
}

\begin{abstract}
ABSTRAK
Tujuan penelitian ini adalah untuk mengetahui kinerja keuangan perusahaan dalam memenuhi kewajiban jangka pendek serta melihat kemampuan dalam mencari keuntungan (laba) pada PT. Matahari Department Store Tbk dan PT. Ramayana Lestari Sentosa Tbk dengan menggunakan alat analisis berupa rasio likuiditas dan profitabilitas untuk periode tahun 2015 - 2017.

Berdasarkan hasil analisis PT. Matahari Department Store Tbk menunjukkan hasil yang kurang baik karena 2 dari 5 aspek rasio likuiditas menunjukkan nilai dibawah rata-rata standar industri sehingga hal tersebut menunjukkan kurang mampunya perusahaan dalam memenuhi kewajiban jangka pendek dengan menggunakan aktiva lancar. Namun berdasarkan hasil analisis rasio profitabilitas menunjukkan nilai yang diperoleh diatas rata-rata walaupun terjadi penurunan disetiap periodenya. Hal tersebut menunjukkan bahwa perusahaan masih mampu dalam mengelola aktiva dan ekuitas serta margin laba bersih.

Kemudian rasio likuiditas yang diperoleh PT. Ramayana Lestari Sentosa Tbk menunjukkan hasil yang baik. Walaupun salah satu rasio yang berkaitan yaitu rasio perputaran kas cenderung stagnan dari 2015 hingga 2017 dengan nilai 1\%. Akan tetapi hal tersebut menunjukkan bahwa perusahaan mampu untuk memenuhi kewajiban jangka pendeknya dengan menggunakan aktiva lancar. Namun berdasarkan hasil analisis rasio profitabilitas menunjukkan bahwa PT. Ramayana Lestari Sentosa Tbk mengalami peningkatan walaupun hasil dari semua aspek rasio profitabilitas tersebut menunjukkan nilai dibawah rata-rata standar. Hal tersebut menunjukkan bahwa perusahaan belum mampu dalam mengelola aktiva dan ekuitas serta margin laba bersih. Dengan demikian pernyataan penelitian yang diajukan tidak dapat diterima.
\end{abstract}

Kata Kunci: Rasio Keuangan, Rasio Likuiditas, Rasio Profitabilitas, Kinerja Keuangan. 


\begin{abstract}
The purpose of this study is to find out the company's financial performance in meeting short-term obligations and see the ability to seek profits (profits) at PT. Matahari Department Store Tbk and PT. Ramayana Lestari Sentosa Tbk by using an analysis tool in the form of liquidity ratios and profitability for the period 2015 $-2017$.

Based on the results of the analysis of PT. Matahari Department Store Tbk shows poor results because 2 of the 5 aspects of the liquidity ratio show values below the industry standard average so that it shows the inability of companies to meet shortterm obligations using current assets. However, based on the results of profitability ratio analysis, the values obtained above the average even though there is a decrease in each period. This shows that the company is still capable of managing assets and equity and net profit margins.

Then the liquidity ratio obtained by PT. Ramayana Lestari Sentosa Tbk showed good results. Although one of the related ratios is the cash turnover ratio tends to be stagnant from 2015 to 2017 with a value of $1 \%$. However, this shows that the company is able to fulfill its short-term obligations using current assets. But based on the results of profitability ratio analysis shows that PT. Ramayana Lestari Sentosa Tbk has increased even though the results of all aspects of profitability ratios show values below the standard average. This shows that the company has not been able to manage assets and equity and net profit margins. Thus the proposed research statement cannot be accepted.
\end{abstract}

Keywords:Financial Ratio, Liquidity Ratio, Profitability Ratio, Performance Finance. 


\section{Pendahuluan}

\section{Latar Belakang}

Kondisi Keuangan perusahaan dapat diketahui dari laporan keuangan yang bersangkutan seperti neraca, laporan rugi laba serta laporan keuangan lainnya. Dengan mengadakan analisis terhadap pos-pos neraca, maka akan dapat diketahui dan diperoleh gambaran mengenai posisi keuangannya. Sedangkan analisis terhadap laporan rugi laba akan memberikan gambaran tentang hasil atau perkembangan dari perusahaan yang bersangkutan. Berdasarkan laporan keuangan yang terdiri dari neraca dan laporan rugi laba dilakukan analisis. Analisis ini menggunakan analisis rasio keuangan, setelah dilakukan analisis akan didapat hasil yang berupa kinerja keuangan perusahaan. Kemudian dari hasil analisis tersebut dapat dipakai sebagai bahan pertimbangan dalam penentuan kebijakan perusahaan.

Untuk menilai suatu kinerja keuangan perusahaan dalam menganalis $\quad \therefore$ s keuangan diperlukan tolak ukur salah satunya yaitu berupa rasio,

menghubungkan dua data keuangan yang satu dengan yang lain. Analisis dan interpretasi dari macam-macam rasio dapat memberikan pandangan yang lebih baik tentang kondisi keuangan perusahaan tersebut. Dengan menggunakan alat analisis diantaranya berupa rasio likuiditas dan rasio profitabilitas.

Rasio likuiditas merupakan salah satu indikator dari beberapa macam indikator yang terdapat dalam rasio keuangan. Rasio likuiditas adalah rasio yang menggambarkan kemampuan perusahaan dalam memenuhi kewajiban jangka pendek serta untuk mengetahui kemampuan perusahaan dalam membiayai dan memenuhi kewajiban (utang) pada saat ditagih. Rasio likuiditas atau sering juga disebut rasio modal kerja merupakan rasio yang digunakan untuk mengukur seberapa likuidnya suatu perusahaan.

Rasio profitabilitas juga merupakan salah satu bagian dari rasio keuangan. Rasio profitabilitas adalah untuk menilai kemampuan perusahaan dalam mencari kentungan. Rasio ini juga memberikan ukuran tingkat efektivitas manajemen suatu perusahaan. Hal ini ditunjukkan oleh laba yang dihasilkan dari penjualan dan pendapatan investasi. Intinya adalah penggunaan rasio ini menunjukkan efisiensi perusahaan.

Perdagangan eceran merupakan salah satu sub-sektor yang banyak dijadikan oleh berbagai perusahaan sebagai bidang utama dalam menjalankan usahanya. Diantara berbagai macam perusahaan yang berjalan pada sub-sektor perdagangan eceran, peneliti memutuskan untuk memilih 2 perusahaan pada bidang sub-sektor perdagangan eceran yang terdapat dalam daftar perusahaan yang terregistrasi di Bursa Efek Indonesia untuk dilakukan penelitian dan akhirnya peneliti memutuskan untuk memilih perusahaan PT. Matahari Department Store Tbk dan PT. Ramayana Lestari Sentosa Tbk sebagai objek penelitian dikarenakan ada beberapa alasan utama yang dimiliki oleh kedua perusahaan tersebut yaitu kedua 
perusahaan ini telah berjalan selama puluhan tahun hingga sekarang (Sehingga memenuhi persyaratan catatan sejarah perusahaan minimal 2 tahun berdasarkan buku panduan skripsi Fakultas Ekonomi Universitas Widya Gama Mahakam Samarinda), lalu kedua perusahaan ini juga bergerak dibidang usaha yang sama yaitu bisnis ritel disektor sandang, selain itu alasan utama lainnya mengapa saya memilih PT. Matahari Department Store Tbk \& PT. Ramayana Lestari Sentosa Tbk adalah karena kedua perusahaan tersebut bergerak dibisnis ritel 'perputaran modalnya cepat' Sehingga membutuhkan tingkat likuiditas dan profitabilitas yang bagus. Perusahaan tersebut harus siap setiap saat untuk memenuhi kewajiban jangka pendeknya, serta mampu dalam mengelola modal kerjanya.

PT. Matahari Department Store Tbk adalah sebuah perusahaan ritel di Indonesia yang menawarkan berbagai macam pilihan produk busana bergaya, aksesori, kecantikan dan peralatan rumah tangga baik dari merek eksklusifnya sendiri maupun internasional. PT. Ramayana Lestari Sentosa Tbk adalah sebuah perusahaan jaringan toko swalayan yang memiliki banyak cabang di Indonesia. Selain department store yang menjual produk sandang seperti baju dan sepatu. Ramayana juga memiliki supermarket atau pasar yang menjual kebutuhan pangan dan sehari-hari.

Berikut ini merupakan sekilas data keuangan mengenai total aktiva, utang lancar, penjualan serta laba PT. Matahari Department Store Tbk dan PT. Ramayana Lestari Sentosa Tbk pada tahun 2015, 2016 dan 2017 yaitu sebagai berikut

Tabel 1 : Ringkasan data akun total aktiva, utang lancar, penjualan dan laba PT. Matahari Department Store Tbk dan PT. Ramayana Lestari Sentosa Tbk periode 2015 - 2017.

\begin{tabular}{||c|c|c|c|c|c|c||}
\hline \multirow{2}{*}{$\begin{array}{c}\text { NAMA } \\
\text { AKUN }\end{array}$} & \multicolumn{6}{|c|}{ (Dalam Jutaan Rupiah) } \\
\cline { 2 - 7 } & \multicolumn{2}{|c|}{ PT. Matahari Department Store Tbk } & \multicolumn{2}{|c|}{ PT. Ramayana Lestari Sentosa Tbk } \\
\cline { 2 - 7 } & 2015 & 2016 & 2017 & 2015 & 2016 & 2017 \\
\hline $\begin{array}{c}\text { Total } \\
\text { Aktiva }\end{array}$ & 3.889 .291 & 4.858 .878 & 5.427 .426 & 4.574 .904 & 4.647 .009 & 4.891 .922 \\
\hline $\begin{array}{c}\text { Utang } \\
\text { Lancar }\end{array}$ & 2.439 .014 & 2.588 .354 & 2.610 .824 & 960.890 & 1.008 .981 & 1.048 .640 \\
\hline Penjualan & 9.006 .893 & 9.897 .046 & 10.023 .961 & 5.533 .004 & 5.857 .037 & 5.622 .728 \\
\hline Laba & 5.671 .255 & 6.211 .767 & 6.261 .940 & 1.996 .004 & 2.202 .498 & 2.212 .294 \\
\hline
\end{tabular}

Sumber Data : IDX (Laporan Keuangan PT. Matahari Department Store Tbk \& PT. Ramayana Lestari Sentosa Tbk). 
Analisis Data Penelitian

A. Rasio Likuiditas

1. Rasio Lancar

Tabel V.1 : Data rasio lancar

(Dalam jutaan Rupiah)

\begin{tabular}{c|c|c|c|c|c|c}
\hline \multirow{2}{*}{$\begin{array}{c}\text { NAMA } \\
\text { AKUN }\end{array}$} & \multicolumn{3}{|c|}{ PT. MATAHARI } & \multicolumn{3}{c}{ PT. RAMAYANA LESTARI } \\
\cline { 2 - 7 } & 2015 & 2016 & 2017 & 2015 & 2016 & 2017 \\
\hline $\begin{array}{l}\text { Aktiva } \\
\text { lancar }\end{array}$ & 2.272 .941 & 2.974 .052 & 2.973 .749 & 2.831 .172 & 2.830 .815 & 3.093 .496 \\
\hline $\begin{array}{c}\text { Utang } \\
\text { lancar }\end{array}$ & 2.439 .014 & 2.588 .354 & 2.610 .824 & 960.890 & 1.008 .981 & 1.048 .640 \\
\hline
\end{tabular}

Sumber Data Diolah

Rasio Lancar (Current ratio)

Rasio Lancar $=\frac{\text { Aktiva Lancar }}{\text { Utang Lancar }}$

Tabel V.2 : Hasil perhitungan analisis rasio lancar

\begin{tabular}{c|c|c}
\hline \multirow{2}{*}{ Tahun } & PT. MATAHARI & PT. RAMAYANA \\
& $\begin{array}{c}\text { DEPARTMENT STORE } \\
\text { TBK }\end{array}$ & TBSTARI SENTOSA \\
\hline 2015 & O,93 X & $2,94 \mathrm{X}$ \\
\hline 2016 & $1,14 \mathrm{X}$ & $2,80 \mathrm{X}$ \\
\hline 2017 & $1,13 \mathrm{X}$ & $2,95 \mathrm{X}$ \\
\hline
\end{tabular}

2. Rasio Cepat

Tabel V.3 : Data rasio cepat

(Dalam jutaan Rupiah)

\begin{tabular}{c|c|c|c|c|c|c}
\hline \multirow{2}{*}{$\begin{array}{c}\text { NAMA } \\
\text { AKUN }\end{array}$} & \multicolumn{3}{|c|}{ PT. MATAHARI } & \multicolumn{3}{c}{ PT. RAMAYANA LESTARI } \\
\cline { 2 - 7 } & 2015 & 2016 & 2017 & 2015 & 2016 & 2017 \\
\hline $\begin{array}{c}\text { Aktiva } \\
\text { lancar }\end{array}$ & 2.272 .941 & 2.974 .052 & 2.973 .749 & 2.831 .172 & 2.830 .815 & 3.093 .496 \\
\hline $\begin{array}{c}\text { Persediaan } \\
\text { DEARTMENT STORE TBK }\end{array}$ & 1.007 .811 & 995.276 & 1.005 .484 & 823.909 & 834.400 & 740.993 \\
\hline $\begin{array}{c}\text { Utang } \\
\text { lancar }\end{array}$ & 2.439 .014 & 2.588 .354 & 2.610 .824 & 960.890 & 1.008 .981 & 1.048 .640 \\
\hline
\end{tabular}

Sumber Data Diolah 
Rasio Cepat (Quick Ratio atau Acid Test Ratio)

Rasio Cepat $=\frac{\text { Aktiva Lancar }- \text { Persediaan }}{\text { Utang Lancar }}$

Tabel V.4 : Hasil perhitungan analisis rasio cepat

\begin{tabular}{c|c|c}
\hline \multirow{2}{*}{ Tahun } & $\begin{array}{c}\text { PT. MATAHARI } \\
\text { DEPARTMENT } \\
\text { STORE TBK }\end{array}$ & $\begin{array}{c}\text { PT. RAMAYANA } \\
\text { LESTARI SENTOSA }\end{array}$ \\
\hline 2015 & $0,51 \mathrm{X}$ & $2,08 \mathrm{X}$ \\
\hline 2016 & $0,76 \mathrm{X}$ & $1,97 \mathrm{X}$ \\
\hline 2017 & $0,75 \mathrm{X}$ & $2,24 \mathrm{X}$ \\
\hline
\end{tabular}

3. Rasio Kas

Tabel V.5 : Data rasio kas

(Dalam jutaan Rupiah)

\begin{tabular}{c|c|c|c|c|c|c}
\hline \multirow{2}{*}{$\begin{array}{c}\text { NAMA } \\
\text { AKUN }\end{array}$} & \multicolumn{3}{|c|}{$\begin{array}{c}\text { PT. MATAHARI } \\
\text { DEPARTMENT STORE TBK }\end{array}$} & \multicolumn{3}{c}{ PT. RAMAYANA LESTARI } \\
SENTOSA TBK \\
\cline { 2 - 7 } & 2015 & 2016 & 2017 & 2015 & 2016 & 2017 \\
\hline $\begin{array}{c}\text { Kas atau } \\
\text { Setara Kas }\end{array}$ & 946.658 & 1.712 .844 & 1.582 .817 & 844.253 & 603.750 & 751.901 \\
\hline $\begin{array}{c}\text { Utang } \\
\text { lancar }\end{array}$ & 2.439 .014 & 2.588 .354 & 2.610 .824 & 960.890 & 1.008 .981 & 1.048 .640 \\
\hline
\end{tabular}

Sumber Data Diolah

Rasio Kas (Cash Ratio)

Rasio Kas $=\frac{\text { Kas atau Setara Kas }}{\text { Utang Lancar }}$

Tabel V.6 : Hasil perhitungan analisis rasio kas

\begin{tabular}{c|c|c}
\hline \multirow{2}{*}{ Tahun } & $\begin{array}{c}\text { PT. MATAHARI } \\
\text { DEPARTMENT } \\
\text { STORE TBK }\end{array}$ & $\begin{array}{c}\text { PT. RAMAYANA } \\
\text { LESTARI SENTOSA }\end{array}$ \\
\hline 2015 & $0,38 \rightarrow 38 \%$ & $0,87 \rightarrow 87 \%$ \\
\hline 2016 & $0,66 \rightarrow 66 \%$ & $0,59 \rightarrow 59 \%$ \\
\hline 2017 & $0,60 \rightarrow 60 \%$ & $0,71 \rightarrow 71 \%$ \\
\hline
\end{tabular}


4. Rasio Perputaran Kas

Tabel V.7 : Data rasio perputaran kas

(Dalam jutaan Rupiah)

\begin{tabular}{c|c|c|c|c|c|c}
\hline \multirow{2}{*}{$\begin{array}{c}\text { NAMA } \\
\text { AKUN }\end{array}$} & \multicolumn{3}{|c|}{ PT. MATAHARI } & \multicolumn{3}{c}{ PT. RAMAYANA LESTARI } \\
\cline { 2 - 7 } DEPARTMENT STORE TBK & \multicolumn{2}{c}{ SENTOSA TBK } \\
\hline $\begin{array}{c}\text { Aktiva } \\
\text { lancar }\end{array}$ & 2.272 .941 & 2.974 .052 & 2.973 .749 & 2.831 .172 & 2.830 .815 & 3.093 .496 \\
\hline $\begin{array}{c}\text { Utang } \\
\text { lancar }\end{array}$ & 2.439 .014 & 2.588 .354 & 2.610 .824 & 960.890 & 1.008 .981 & 1.048 .640 \\
\hline $\begin{array}{c}\text { Penjualan } \\
\text { Bersih* }\end{array}$ & 5.671 .255 & 6.211 .767 & 6.261 .940 & 1.996 .004 & 2.202 .498 & 2.212 .294 \\
\hline
\end{tabular}

Sumber Data Diolah

Rasio Perputaran Kas (Cash Turn Over)

Rasio Perputaran Kas = Penjualan Bersih

Modal Kerja Bersih

Untuk mencari modal kerja bersih, dengan cara mengurangi aktiva lancar terhadap utang lancar, maka jadilah rumus sebagai berikut :

$$
\text { Rasio Perputaran Kas }=\frac{\text { Penjualan Bersih }}{\text { Aktiva Lancar }- \text { Utang Lancar }}
$$

Tabel V.8 : Hasil perhitungan analisis rasio perputaran kas

\begin{tabular}{c|c|c}
\hline \multirow{2}{*}{ Tahun } & $\begin{array}{c}\text { PT. MATAHARI } \\
\text { DEPARTMENT } \\
\text { STORE TBK }\end{array}$ & $\begin{array}{c}\text { PT. RAMAYANA } \\
\text { LESTARI SENTOSA }\end{array}$ \\
\hline 2015 & $-34,14 \mathrm{X} \rightarrow-34 \%$ & $1,06 \mathrm{X} \rightarrow 1 \%$ \\
\hline 2016 & $16,10 \mathrm{X} \rightarrow 16 \%$ & $1,20 \rightarrow 1 \%$ \\
\hline 2017 & $17,25 \rightarrow 17 \%$ & $1,08 \rightarrow 1 \%$ \\
\hline
\end{tabular}

5. Inventory to Net Working Capital

Tabel V.9 : Data inventory to net working capital

(Dalam jutaan Rupiah)

NAMA

PT. MATAHARI

AKUN DEPARTMENT STORE TBK PT. RAMAYANA LESTARI SENTOSA TBK

\begin{tabular}{l|l|l|l}
2015 & 2016 & 2017 & 2015
\end{tabular}

2016
2017 


\begin{tabular}{c|c|c|c|c|c|c}
\hline $\begin{array}{c}\text { Aktiva } \\
\text { lancar }\end{array}$ & 2.272 .941 & 2.974 .052 & 2.973 .749 & 2.831 .172 & 2.830 .815 & 3.093 .496 \\
\hline Persediaan & 1.007 .811 & 995.276 & 1.005 .484 & 823.909 & 834.400 & 740.993 \\
\hline $\begin{array}{c}\text { Utang } \\
\text { lancar }\end{array}$ & 2.439 .014 & 2.588 .354 & 2.610 .824 & 960.890 & 1.008 .981 & 1.048 .640 \\
\hline
\end{tabular}

Sumber Data Diolah

\section{Inventory to Net Working Capital}

Inventory to Net Working Capital $=$

Persediaan

Aktiva Lancar - Utang Lancar

Tabel V.10 : Hasil perhitungan analisis inventory to net working capital

\begin{tabular}{c|c|c}
\hline \multirow{2}{*}{ Tahun } & $\begin{array}{c}\text { PT. MATAHARI } \\
\text { DEPARTMENT } \\
\text { STORE TBK }\end{array}$ & $\begin{array}{c}\text { PT. RAMAYANA } \\
\text { LESTARI SENTOSA } \\
\text { TBK }\end{array}$ \\
\hline 2015 & $-6,068 \rightarrow-607 \%$ & $0,440 \rightarrow 44 \%$ \\
\hline 2016 & $2,580 \rightarrow 258 \%$ & $0,458 \rightarrow 46 \%$ \\
\hline 2017 & $2,770 \rightarrow 277 \%$ & $0,362 \rightarrow 36 \%$ \\
\hline
\end{tabular}

B.

Rasio Profitabilitas

1. Net Profit Margin

Tabel V.11 : Data net profit margin

(Dalam jutaan Rupiah)

\begin{tabular}{|c|c|c|c|c|c|c|}
\hline \multirow{2}{*}{$\begin{array}{l}\text { NAMA } \\
\text { AKUN }\end{array}$} & \multicolumn{3}{|c|}{$\begin{array}{c}\text { PT. MATAHARI } \\
\text { DEPARTMENT STORE TBK }\end{array}$} & \multicolumn{3}{|c|}{$\begin{array}{c}\text { PT. RAMAYANA LESTARI } \\
\text { SENTOSA TBK }\end{array}$} \\
\hline & 2015 & 2016 & 2017 & 2015 & 2016 & 2017 \\
\hline $\begin{array}{c}\text { EAIT } \\
\text { (Laba } \\
\text { Sesudah } \\
\text { Bunga \& } \\
\text { Pajak) }\end{array}$ & 1.780 .848 & 2.019 .705 & 1.907 .077 & 336.054 & 408.479 & 406.580 \\
\hline Penjualan & 9.006 .893 & 9.897 .046 & 10.023 .961 & 5.533 .004 & 5.857 .037 & 5.622 .728 \\
\hline
\end{tabular}

Sumber Data Diolah

Net Profit Margin

Net Profit Margin = Laba Sesudah Bunga dan Pajak

Penjualan 
Tabel V.12 : Hasil perhitungan analisis net profit margin

\begin{tabular}{c|c|c}
\hline \multirow{2}{*}{ Tahun } & $\begin{array}{c}\text { PT. MATAHARI } \\
\text { DEPARTMENT STORE } \\
\text { TBK }\end{array}$ & $\begin{array}{c}\text { PT. RAMAYANA } \\
\text { LESTARI SENTOSA } \\
\text { TBK }\end{array}$ \\
\hline 2015 & $0,1977 \rightarrow 20 \%$ & $0,0607 \rightarrow 6 \%$ \\
\hline 2016 & $0,2040 \rightarrow 20 \%$ & $0,0697 \rightarrow 7 \%$ \\
\hline 2017 & $0,1902 \rightarrow 19 \%$ & $0,0723 \rightarrow 7 \%$ \\
\hline
\end{tabular}

2. Return On Investment

Tabel V.13 : Data return on investment

(Dalam jutaan Rupiah)

\begin{tabular}{c|c|c|c|c|c|c}
\hline \multirow{2}{*}{$\begin{array}{c}\text { NAMA } \\
\text { AKUN }\end{array}$} & \multicolumn{3}{|c|}{ PT. MATAHARI } & \multicolumn{3}{c}{ PT. RAMAYANA LESTARI } \\
\cline { 2 - 7 } & 2015 & 2016 & 2017 & 2015 & 2016 & 2017 \\
\hline $\begin{array}{c}\text { EAIT } \\
\text { (Laba } \\
\text { Sesudah } \\
\text { Bunga } \\
\text { \& } \\
\text { Pajak) }\end{array}$ & 1.780 .848 & 2.019 .705 & 1.907 .077 & 336.054 & 408.479 & 406.580 \\
\hline $\begin{array}{c}\text { Total } \\
\text { Aktiva } \\
\text { (Aset) }\end{array}$ & 3.889 .291 & 4.858 .878 & 5.427 .426 & 4.574 .904 & 4.647 .009 & 4.891 .922 \\
\hline
\end{tabular}

Sumber Data Diolah

\section{Return On Investment} Return On Investment $=\frac{\text { Laba Sesudah Bunga dan Pajak }}{\text { Total Aktiva }}$

Tabel V.14 : Hasil perhitungan analisis return on investment

\begin{tabular}{c|c|c}
\hline \multirow{2}{*}{ Tahun } & $\begin{array}{c}\text { PT. MATAHARI } \\
\text { DEPARTMENT STORE } \\
\text { TBK }\end{array}$ & $\begin{array}{c}\text { PT. RAMAYANA } \\
\text { LESTARI SENTOSA } \\
\text { TBK }\end{array}$ \\
\hline 2015 & $0,457 \rightarrow 46 \%$ & $0,073 \rightarrow 7 \%$ \\
\hline 2016 & $0,415 \rightarrow 42 \%$ & $0,087 \rightarrow 8 \%$ \\
\hline 2017 & $0,351 \rightarrow 35 \%$ & $0,083 \rightarrow 8 \%$ \\
\hline
\end{tabular}


3. Return On Equity

Tabel V.15 : Data return on equity

(Dalam jutaan Rupiah)

\begin{tabular}{c|c|c|c|c|c|c}
\hline \multirow{2}{*}{$\begin{array}{c}\text { NAMA } \\
\text { AKUN }\end{array}$} & \multicolumn{3}{|c|}{ PT. MATAHARI } & \multicolumn{3}{c}{ PT. RAMAYANA LESTARI } \\
\cline { 2 - 7 } & 2015 & 2016 & 2017 & 2015 & 2016 & 2017 \\
\hline $\begin{array}{c}\text { EAIT } \\
\text { Laba }\end{array}$ & & & & & & \\
$\begin{array}{c}\text { Sesudah } \\
\text { Bunga } \\
\text { \& } \\
\text { Pajak) }\end{array}$ & 1.780 .848 & 2.019 .705 & 1.907 .077 & 336.054 & 408.479 & 406.580 \\
\hline $\begin{array}{c}\text { Total } \\
\text { Ekuitas }\end{array}$ & 1.106 .167 & 1.855 .243 & 2.327 .985 & 3.333 .804 & 3.337 .399 & 3.494 .345 \\
\hline
\end{tabular}

Sumber Data Diolah

Return On Equity

Return On Equity $=\frac{\text { Laba Sesudah Bunga dan Pajak }}{\text { Total Ekuitas }}$

Tabel V.16 : Hasil perhitungan analisis return on equity

\begin{tabular}{c|c|c}
\hline \multirow{2}{*}{ Tahun } & $\begin{array}{c}\text { PT. MATAHARI } \\
\text { DEPARTMENT STORE } \\
\text { TBK }\end{array}$ & $\begin{array}{c}\text { PT. RAMAYANA } \\
\text { LESTARI SENTOSA } \\
\text { TBK }\end{array}$ \\
\hline 2015 & $160,9 \rightarrow 161 \%$ & $10,0 \rightarrow 10 \%$ \\
\hline 2016 & $108,8 \rightarrow 109 \%$ & $12,2 \rightarrow 12 \%$ \\
\hline 2017 & $81,9 \rightarrow 82 \%$ & $11,6 \rightarrow 12 \%$ \\
\hline
\end{tabular}

\section{Pembahasan}

Tabel V.17 : Ringkasan dari hasil pengujian

\begin{tabular}{c|c|c|c|c|c|c|c}
\hline \multirow{2}{*}{$\begin{array}{c}\text { Jenis } \\
\text { Rasio }\end{array}$} & \multirow{2}{*}{$\begin{array}{c}\text { Rata- Rata } \\
\text { Industri }\end{array}$} & \multicolumn{3}{|c|}{$\begin{array}{c}\text { PT. MATAHARI } \\
\text { DEPARTMENT }\end{array}$} & \multicolumn{3}{c}{$\begin{array}{c}\text { PT. RAMAYANA } \\
\text { LESTRI SENTOSA }\end{array}$} \\
\cline { 3 - 8 } & & 2015 & 2016 & 2017 & 2015 & 2016 & 2017 \\
\hline \multirow{2}{*}{$\begin{array}{c}\text { Rasio } \\
\text { Lancar }\end{array}$} & \multirow{2}{*}{$2 \mathrm{kali}$} & 0,93 & 1,14 & 1,13 & 2,94 & 2,80 & 2,95 \\
& & $\mathrm{kali}$ & $\mathrm{kali}$ & $\mathrm{kali}$ & $\mathrm{kali}$ & $\mathrm{kali}$ & $\mathrm{kali}$ \\
\hline Rasio & \multirow{2}{*}{$1,5 \mathrm{kali}$} & 0,51 & 0,76 & 0,75 & 2,08 & 1,97 & 2,24 \\
Cepat & & $\mathrm{kali}$ & $\mathrm{kali}$ & $\mathrm{kali}$ & $\mathrm{kali}$ & $\mathrm{kali}$ & $\mathrm{kali}$ \\
\hline Rasio Kas & $50 \%$ & $38 \%$ & $66 \%$ & $60 \%$ & $87 \%$ & $59 \%$ & $71 \%$ \\
\hline
\end{tabular}




\begin{tabular}{c|c|c|c|c|c|c|c}
\hline $\begin{array}{c}\text { Rasio } \\
\text { Perputaran } \\
\text { Kas }\end{array}$ & $10 \%$ & $-34 \%$ & $16 \%$ & $17 \%$ & $1 \%$ & $1 \%$ & $1 \%$ \\
\hline $\begin{array}{c}\text { Inventory } \\
\text { to Net } \\
\text { Working } \\
\text { Capital }\end{array}$ & $12 \%$ & $-607 \%$ & $258 \%$ & $277 \%$ & $44 \%$ & $46 \%$ & $36 \%$ \\
\hline $\begin{array}{c}\text { Net Profit } \\
\text { Margin }\end{array}$ & $20 \%$ & $20 \%$ & $20 \%$ & $19 \%$ & $6 \%$ & $7 \%$ & $7 \%$ \\
\hline $\begin{array}{c}\text { Return On } \\
\text { Investment }\end{array}$ & $30 \%$ & $46 \%$ & $42 \%$ & $35 \%$ & $7 \%$ & $9 \%$ & $8 \%$ \\
\hline $\begin{array}{c}\text { Return On } \\
\text { Equity }\end{array}$ & $40 \%$ & $161 \%$ & $109 \%$ & $82 \%$ & $10 \%$ & $12 \%$ & $12 \%$ \\
\hline
\end{tabular}

Keterangan :

: Menunjukkan bahwa nilai dibawah rata-rata industri : Menunjukkan bahwa nilai diatas rata-rata industri

\section{Gambar V.1 : Grafik komparasi hasil analisis rasio lancar}

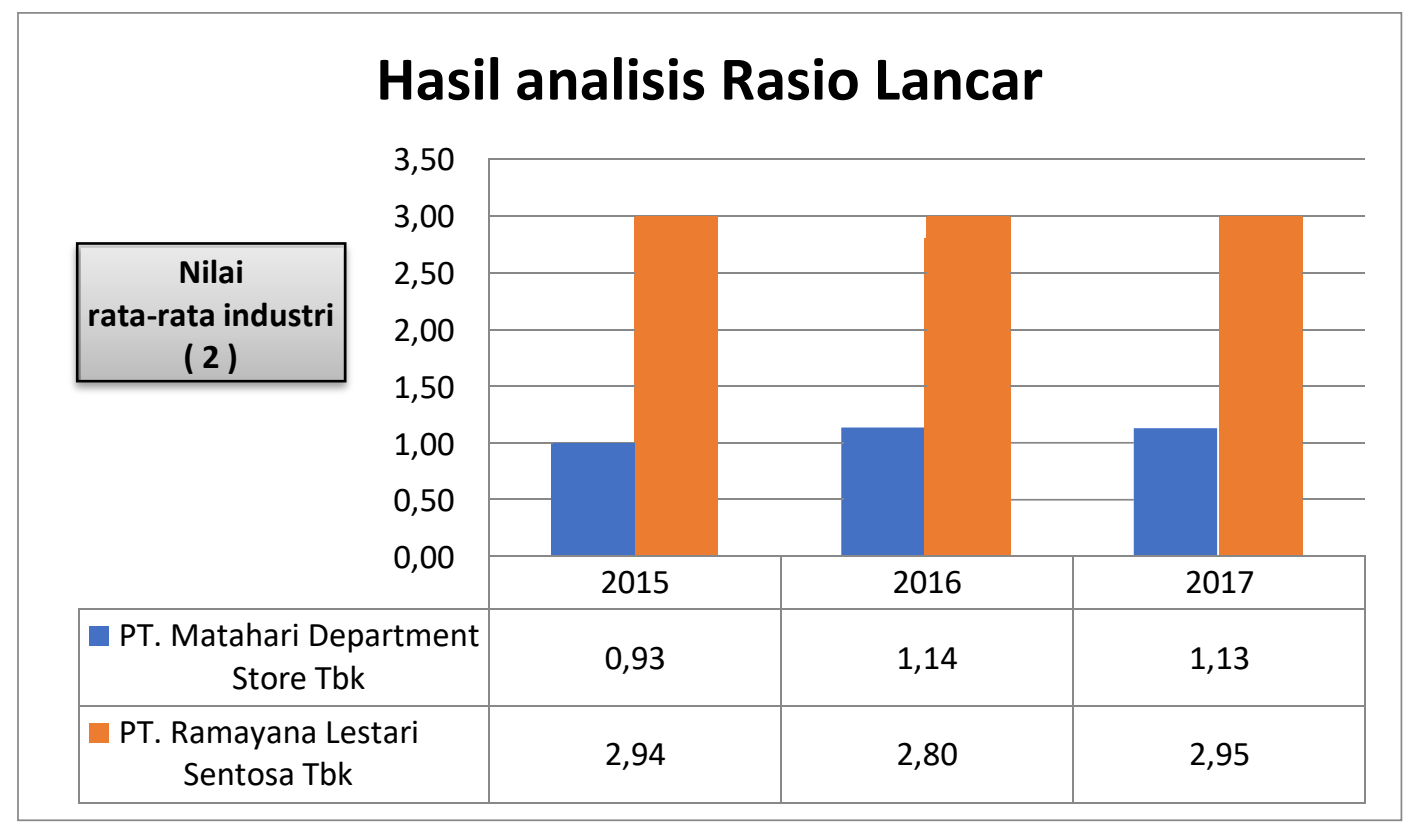

Berdasarkan analisis rasio lancar, Hal tersebut disebabkan adanya fluktuasi yang terjadi pada Aktiva lancar dan Utang lancar periode tahun 2015, 2016 dan 2017, yaitu sebagai berikut: 
Tabel V.18 : Perubahan nilai persentase akun yang berkaitan dengan rasio lancar pada periode tahun 2015-2017

\begin{tabular}{|c|c|c|c|c|c|c|}
\hline \multirow{2}{*}{$\begin{array}{l}\text { NAMA } \\
\text { AKUN }\end{array}$} & \multicolumn{3}{|c|}{$\begin{array}{c}\text { PT. MATAHARI } \\
\text { DEPARTMENT STORE TBK }\end{array}$} & \multicolumn{3}{|c|}{$\begin{array}{c}\text { PT. RAMAYANA LESTARI } \\
\text { SENTOSA TBK }\end{array}$} \\
\hline & 2015 & 2016 & 2017 & 2015 & 2016 & 2017 \\
\hline $\begin{array}{l}\text { Aktiva } \\
\text { lancar }\end{array}$ & 2.272 .941 & $\begin{array}{l}2.974 .052 \\
(\uparrow 30,84 \%)\end{array}$ & $\begin{array}{l}2.973 .749 \\
(\downarrow 0,01 \%)\end{array}$ & 2.831 .172 & $\begin{array}{l}2.830 .815 \\
(\downarrow 0,01 \%)\end{array}$ & $\begin{array}{l}3.093 .496 \\
(\uparrow 9,27 \%)\end{array}$ \\
\hline $\begin{array}{l}\text { Utang } \\
\text { lancar }\end{array}$ & 2.439 .014 & $\begin{array}{l}2.588 .354 \\
(\uparrow 6,12 \%)\end{array}$ & $\begin{array}{l}2.610 .824 \\
(\uparrow 0,86 \%)\end{array}$ & 960.890 & $\begin{array}{l}1.008 .981 \\
(\uparrow 5 \%)\end{array}$ & $\begin{array}{l}1.048 .640 \\
(\uparrow 3,93 \%)\end{array}$ \\
\hline
\end{tabular}

menunjukkan nilai rasio yang tidak sehat yaitu senilai 0,93 kali (2015), 1,14 kali (2016) dan 1,13 kali (2017). Dimana nilai dari ketiga tahun tersebut masih dibawah nilai rata-rata industri untuk rasio lancar yaitu senilai 2 kali atau 2:1. Walaupun nilai rata-rata industri sebesar 2 kali itu tidak mutlak. Akan tetapi hal tersebut mengindikasikan bahwa kurang baiknya kemampuan PT. Matahari Department Store Tbk dalam upaya untuk membayar utang lancar dengan menggunakan aktiva lancar.

Tabel V.19 : Perubahan nilai persentase akun yang berkaitan dengan rasio cepat pada periode tahun 2015-2017

\begin{tabular}{c|c|c|c|c|c|c}
\hline \multirow{2}{*}{$\begin{array}{c}\text { NAMA } \\
\text { AKUN }\end{array}$} & \multicolumn{3}{|c|}{ PT. MATAHARI } & \multicolumn{2}{c}{$\begin{array}{c}\text { PT. RAMAYANA LESTARI } \\
\text { DEPARTMENT STORE TBK }\end{array}$} & \multicolumn{2}{c}{ SENTOSA TBK } \\
\cline { 2 - 7 } & 2015 & 2016 & 2017 & 2015 & 2016 & 2017 \\
\hline $\begin{array}{c}\text { Aktiva } \\
\text { lancar }\end{array}$ & 2.272 .941 & $\begin{array}{c}2.974 .052 \\
(\uparrow 30,84 \%)\end{array}$ & $\begin{array}{c}2.973 .749 \\
(\downarrow 0,01 \%)\end{array}$ & 2.831 .172 & $\begin{array}{c}2.830 .815 \\
(\downarrow 0,01 \%)\end{array}$ & $\begin{array}{c}3.093 .496 \\
(\uparrow 9,27 \%)\end{array}$ \\
\hline Persediaan & 1.007 .811 & $\begin{array}{c}995.276 \\
(\downarrow 1,24 \%)\end{array}$ & $\begin{array}{c}1.005 .484 \\
(\uparrow 1 \%)\end{array}$ & 823.909 & $\begin{array}{c}834.400 \\
(\uparrow 1,2 \%)\end{array}$ & $\begin{array}{c}740.993 \\
(\downarrow 11,1 \%)\end{array}$ \\
\hline $\begin{array}{c}\text { Utang } \\
\text { lancar }\end{array}$ & 2.439 .014 & $\begin{array}{c}2.588 .354 \\
(\uparrow 6,12 \%)\end{array}$ & $\begin{array}{c}2.610 .824 \\
(\uparrow 0,86 \%)\end{array}$ & 960.890 & $\begin{array}{c}1.008 .981 \\
(\uparrow 5 \%)\end{array}$ & $\begin{array}{c}1.048 .640 \\
(\uparrow 3,93 \%)\end{array}$ \\
\hline
\end{tabular}

Pada perusahaan PT. Matahari Department Store Tbk, berdasarkan analisis rasio cepat menunjukkan bahwa nilai selama 3 tahun periode tersebut masih dibawah rata-rata industri yaitu 0,51 kali (2015), 0,76 kali (2016) dan 0,75 kali (2017). Nilai yang didapat masih dibawah rata-rata industri yakni 1,5 kali. Hal tersebut menunjukkan bahwa kurangnya kemampuan perusahaan dalam membayar 
utang yang harus segera dilunasi (utang lancar) dengan menggunakan aktiva lancar (tanpa persediaan).

Sedangkan nilai rasio cepat yang didapatkan PT. Ramayana Lestari Sentosa Tbk mengalami fluktuasi yang sama, Akan tetapi nilai yang diperoleh sudah diatas nilai rata-rata industri yaitu 2,08 kali (2015), 1,97 kali (2016) dan 2,24 kali (2017). Hal tersebut menunjukkan bahwa adanya kemampuan perusahaan dalam membayar utang lancar dengan menggunakan aktiva lancar (tanpa persediaan).

\section{Gambar V.3 : Grafik komparasi hasil analisis rasio kas}

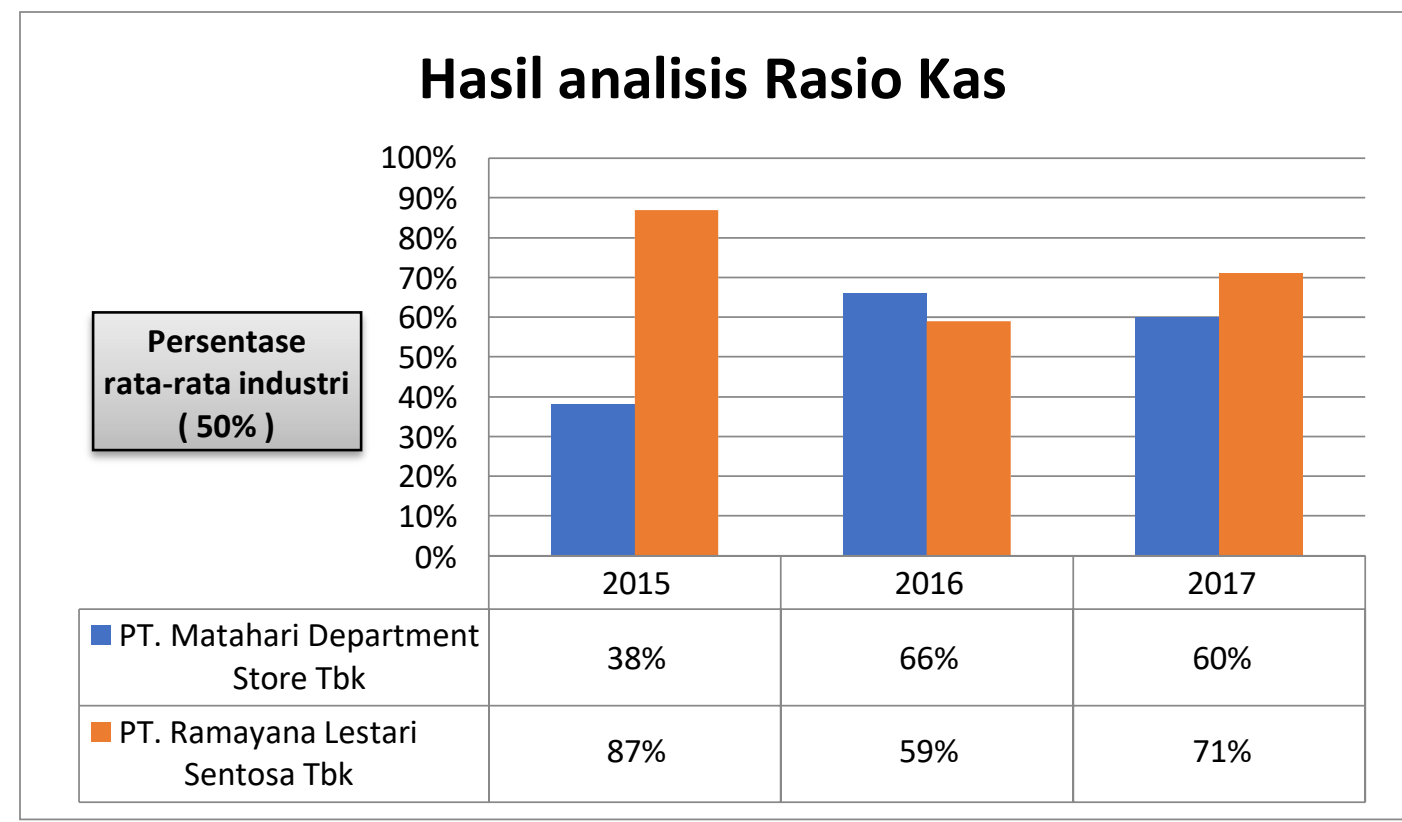

Berdasarkan analisis rasio kas, pada tahun 2015 nilai yang diperoleh PT. Matahari Department Store Tbk berada dibawah rata-rata yang telah ditetapkan yaitu senilai $38 \%$. Sedangkan nilai rata-rata industri untuk rasio kas adalah 50\%, namun pada tahun 2016 dan 2017 terjadi peningkatan sehingga nilai rasio kas yang diperoleh berada diatas nilai rata-rata industri yaitu 66\% (2016) dan 60\% (2017). Hal itu disebabkan oleh beberapa akun yang mengalami fluktuasi diantaranya Kas dan setara kas dan Utang lancar pada periode tahun 2015, 2016 dan 2017 yaitu sebagai berikut : Tabel V.20 : Perubahan nilai persentase akun yang berkaitan dengan rasio kas pada periode tahun 2015-2017

\begin{tabular}{|c|c|c|c|c|c|c|}
\hline \multirow{2}{*}{$\begin{array}{l}\text { NAMA } \\
\text { AKUN }\end{array}$} & \multicolumn{3}{|c|}{$\begin{array}{c}\text { PT. MATAHARI } \\
\text { DEPARTMENT STORE TBK }\end{array}$} & \multicolumn{3}{|c|}{$\begin{array}{c}\text { PT. RAMAYANA LESTARI } \\
\text { SENTOSA TBK }\end{array}$} \\
\hline & 2015 & 2016 & 2017 & 2015 & 2016 & 2017 \\
\hline $\begin{array}{c}\text { Kas atau } \\
\text { Setara } \\
\text { Kas }\end{array}$ & 946.658 & $\begin{array}{l}1.712 .844 \\
(\uparrow 80,9 \%)\end{array}$ & $\begin{array}{l}1.582 .817 \\
(\downarrow 7,5 \%)\end{array}$ & 844.253 & $\begin{array}{c}603.750 \\
(\downarrow 28,4 \%)\end{array}$ & $\begin{array}{l}751.901 \\
(\uparrow 24,5 \%)\end{array}$ \\
\hline
\end{tabular}




\begin{tabular}{c|c|c|c|c|c|c}
\hline $\begin{array}{c}\text { Utang } \\
\text { lancar }\end{array}$ & 2.439 .014 & $\begin{array}{c}2.588 .354 \\
(\uparrow 6,12 \%)\end{array}$ & $\begin{array}{c}2.610 .824 \\
(\uparrow 0,86 \%)\end{array}$ & 960.890 & $\begin{array}{c}1.008 .981 \\
(\uparrow 5 \%)\end{array}$ & $\begin{array}{c}1.048 .640 \\
(\uparrow 3,93 \%)\end{array}$ \\
\hline
\end{tabular}

Hal tersebut menunjukkan bahwa adanya kemampuan perusahaan PT. Matahari Department Store Tbk dalam membayar utang lancar dengan menggunakan kas dan setara kas yang dimiliki.

Sedangkan rasio kas PT. Ramayana Lestari Sentosa Tbk masih sama dengan rasio lancar dan rasio cepat yang cenderung berfluktuasi dari tahun 2015 hingga 2017 yaitu senilai 87\% (2015), 59\% (2016) dan 71\% (2017). Walaupun terjadi ketidakstabilan dari tahun ke tahun akan tetapi berdasarkan nilai rata-rata industri yang berlaku bahwa nilai rasio kas PT. Ramayana Lestari Sentosa Tbk berada diatas nilai rata-rata. Hal tersebut menunjukkan bahwa adanya kemampuan perusahaan dalam membayar utang lancar dengan menggunakan kas dan setara kas yang dimiliki perusahaan.

Gambar V.4 : Grafik komparasi hasil analisis rasio perputaran kas

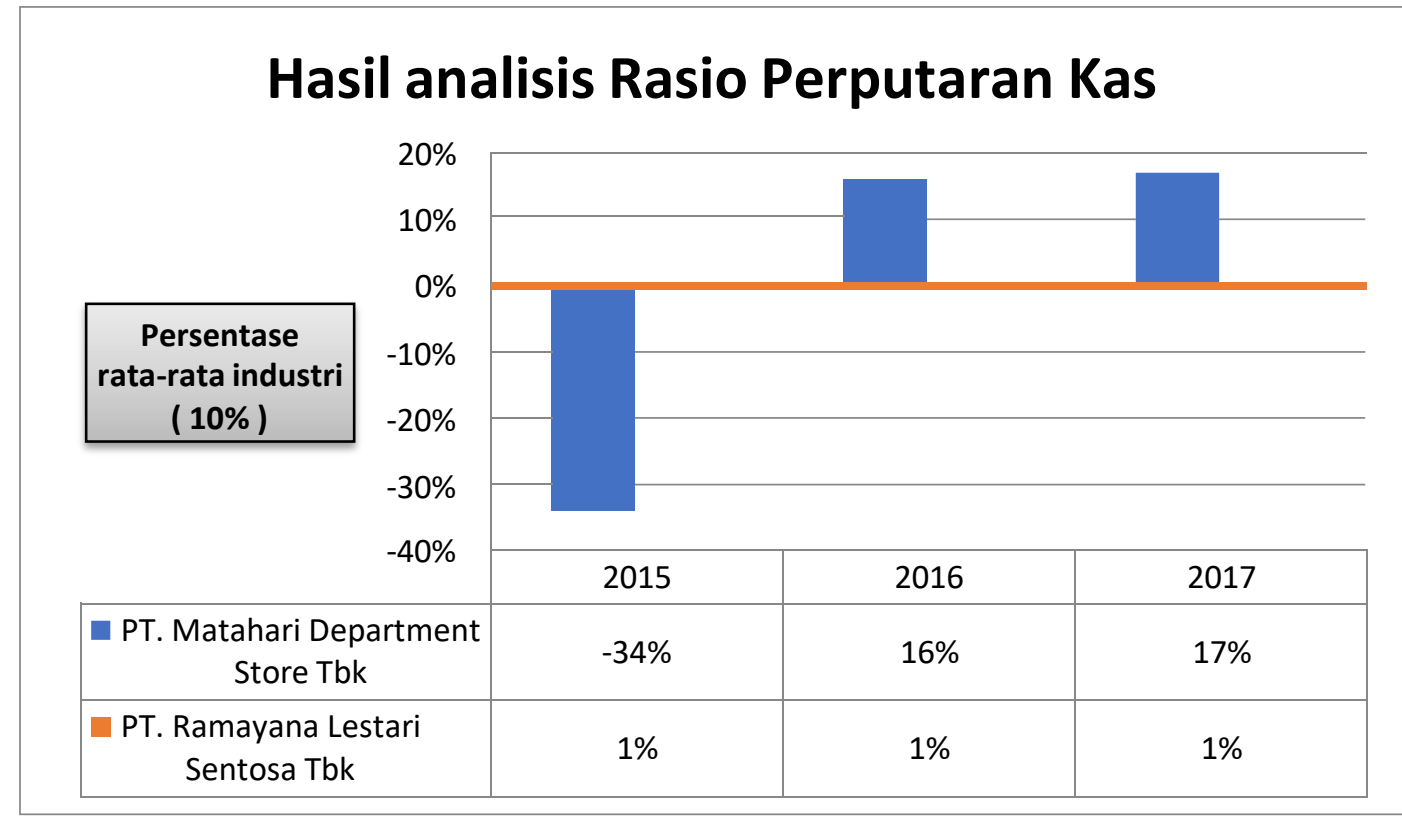

Berdasarkan analisis rasio perputaran kas, pada tahun 2015 nilai rasio yang diperoleh PT. Matahari Department Store Tbk bahkan menyentuh angka negatif yaitu senilai (-34\%). Akan tetapi rasio perputaran kas pada tahun 2016 dan 2017 mengalami peningkatan menjadi positif senilai $16 \%$ dan $17 \%$. Hal tersebut disebabkan adanya fluktuasi yang terjadi pada Aktiva lancar serta peningkatan pada Utang lancar dan Penjualan bersih pada periode tahun 20152016 dan 2017 yaitu sebagai berikut : 
Tabel V.21 : Perubahan nilai persentase akun yang berkaitan dengan rasio perputaran kas pada periode tahun 2015-2017

\begin{tabular}{|c|c|c|c|c|c|c|}
\hline \multirow{2}{*}{$\begin{array}{l}\text { NAMA } \\
\text { AKUN }\end{array}$} & \multicolumn{3}{|c|}{$\begin{array}{c}\text { PT. MATAHARI } \\
\text { DEPARTMENT STORE TBK }\end{array}$} & \multicolumn{3}{|c|}{$\begin{array}{c}\text { PT. RAMAYANA LESTARI } \\
\text { SENTOSA TBK }\end{array}$} \\
\hline & 2015 & 2016 & 2017 & 2015 & 2016 & 2017 \\
\hline $\begin{array}{l}\text { Aktiva } \\
\text { lancar }\end{array}$ & 2.272 .941 & $\begin{array}{c}2.974 .052 \\
(\uparrow 30,84 \%)\end{array}$ & $\begin{array}{l}2.973 .749 \\
(\downarrow 0,01 \%)\end{array}$ & 2.831 .172 & $\begin{array}{l}2.830 .815 \\
(\downarrow 0,01 \%)\end{array}$ & $\begin{array}{l}3.093 .496 \\
(\uparrow 9,27 \%)\end{array}$ \\
\hline $\begin{array}{l}\text { Utang } \\
\text { lancar }\end{array}$ & 2.439 .014 & $\begin{array}{l}2.588 .354 \\
(\uparrow 6,12 \%)\end{array}$ & $\begin{array}{l}2.610 .824 \\
(\uparrow 0,86 \%)\end{array}$ & 960.890 & $\begin{array}{l}1.008 .981 \\
(\uparrow 5 \%)\end{array}$ & $\begin{array}{l}1.048 .640 \\
(\uparrow 3,93 \%)\end{array}$ \\
\hline $\begin{array}{l}\text { Penjualan } \\
\text { Bersih* }\end{array}$ & 5.671 .255 & $\begin{array}{l}6.211 .767 \\
(\uparrow 9,53 \%)\end{array}$ & $\begin{array}{l}6.261 .940 \\
(\uparrow 0,80 \%)\end{array}$ & 1.996 .004 & $\begin{array}{l}2.202 .498 \\
(\uparrow 10,34 \%)\end{array}$ & $\begin{array}{l}2.212 .294 \\
(\uparrow 0,44 \%)\end{array}$ \\
\hline
\end{tabular}

Jadi berdasarkan hasil analisis berarti perusahaan memiliki peningkatan kemampuan untuk menutupi biaya-biaya perusahaan. Karena nilai yang didapat melebihi rata-rata industri yang telah ditetapkan yaitu $10 \%$.

Sedangkan rasio perputaran kas PT. Ramayana Lestari Sentosa Tbk pada tahun 2015 hingga 2017 menunjukkan nilai yang cenderung stagnan dengan ratarata nilai persentase yang sama yaitu senilai $1 \%$. Berdasarkan nilai yang didapat menunjukkan dibawah rata-rata industri yang ditetapkan. Hal tersebut menunjukkan bahwa kurang mampunya ketersediaan kas untuk membayar tagihan (utang) dan biaya-biaya yang berkaitan dengan penjualan.

Gambar V.5 : Grafik komparasi hasil analisis inventory to net working

Capital

\section{Hasil analisis Inventory To Net Working Capital}

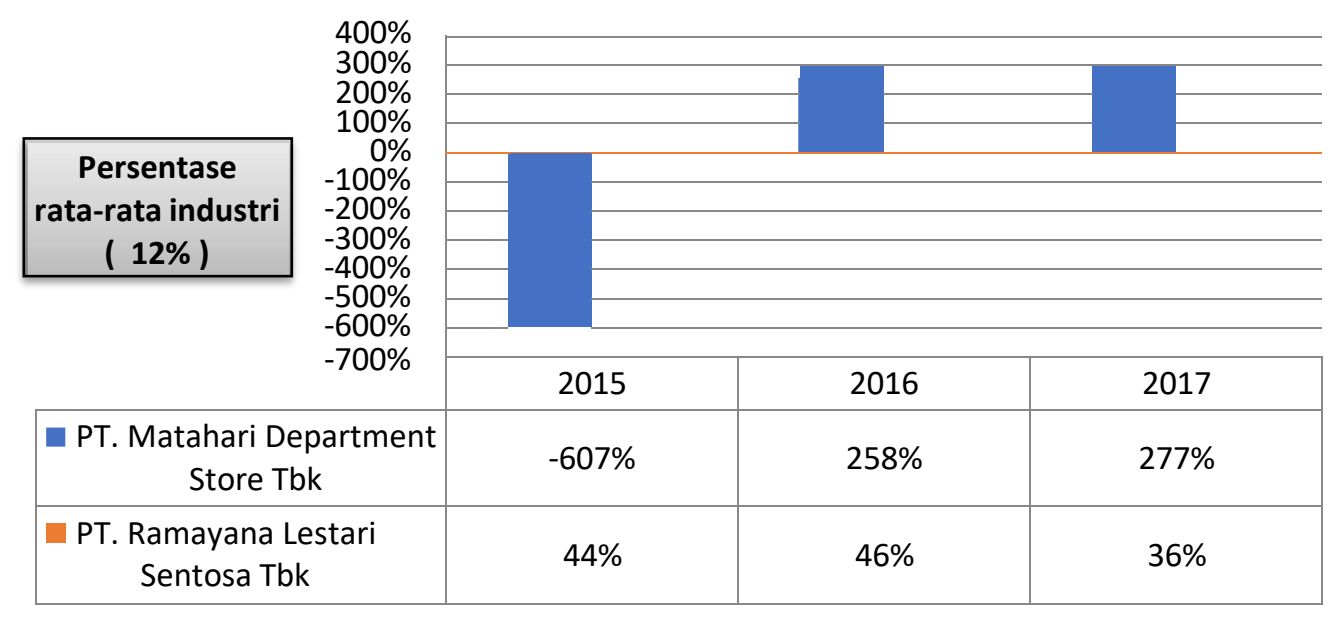


Tabel V.22 : Perubahan nilai persentase akun yang berkaitan dengan inventory to net working capital pada periode tahun 2015-2017

\begin{tabular}{c|c|c|c|c|c|c}
\hline \multirow{2}{*}{$\begin{array}{c}\text { NAMA } \\
\text { AKUN }\end{array}$} & \multicolumn{3}{|c|}{$\begin{array}{c}\text { PT. MATAHARI } \\
\text { DEPARTMENT STORE TBK }\end{array}$} & \multicolumn{3}{c}{$\begin{array}{c}\text { PT. RAMAYANA LESTARI } \\
\text { SENTOSA TBK }\end{array}$} \\
\cline { 2 - 7 } & 2015 & 2016 & 2017 & 2015 & 2016 & 2017 \\
\hline $\begin{array}{c}\text { Aktiva } \\
\text { lancar }\end{array}$ & 2.272 .941 & $\begin{array}{c}2.974 .052 \\
(\uparrow 30,84 \%)\end{array}$ & $\begin{array}{c}2.973 .749 \\
(\downarrow 0,01 \%)\end{array}$ & 2.831 .172 & $\begin{array}{c}2.830 .815 \\
(\downarrow 0,01 \%)\end{array}$ & $\begin{array}{c}3.093 .496 \\
(\uparrow 9,27 \%)\end{array}$ \\
\hline Persediaan & 1.007 .811 & $\begin{array}{c}995.276 \\
(\downarrow 1,24 \%)\end{array}$ & $\begin{array}{c}1.005 .484 \\
(\uparrow 1 \%)\end{array}$ & 823.909 & $\begin{array}{c}834.400 \\
(\uparrow 1,2 \%)\end{array}$ & $\begin{array}{c}740.993 \\
(\downarrow 11,1 \%)\end{array}$ \\
\hline $\begin{array}{c}\text { Utang } \\
\text { lancar }\end{array}$ & 2.439 .014 & $\begin{array}{c}2.588 .354 \\
(\uparrow 6,12 \%)\end{array}$ & $\begin{array}{c}2.610 .824 \\
(\uparrow 0,86 \%)\end{array}$ & 960.890 & $\begin{array}{c}1.008 .981 \\
(\uparrow 5 \%)\end{array}$ & $\begin{array}{c}1.048 .640 \\
(\uparrow 3,93 \%)\end{array}$ \\
\hline
\end{tabular}

Dapat diartikan bahwa PT. Matahari Department Store Tbk mengalami peningkatan kemampuan untuk menutupi biaya-biaya perusahaan seperti utang lancar dan pembiayaan persediaan.

Gambar V.6 : Grafik komparasi hasil analisis net profit margin

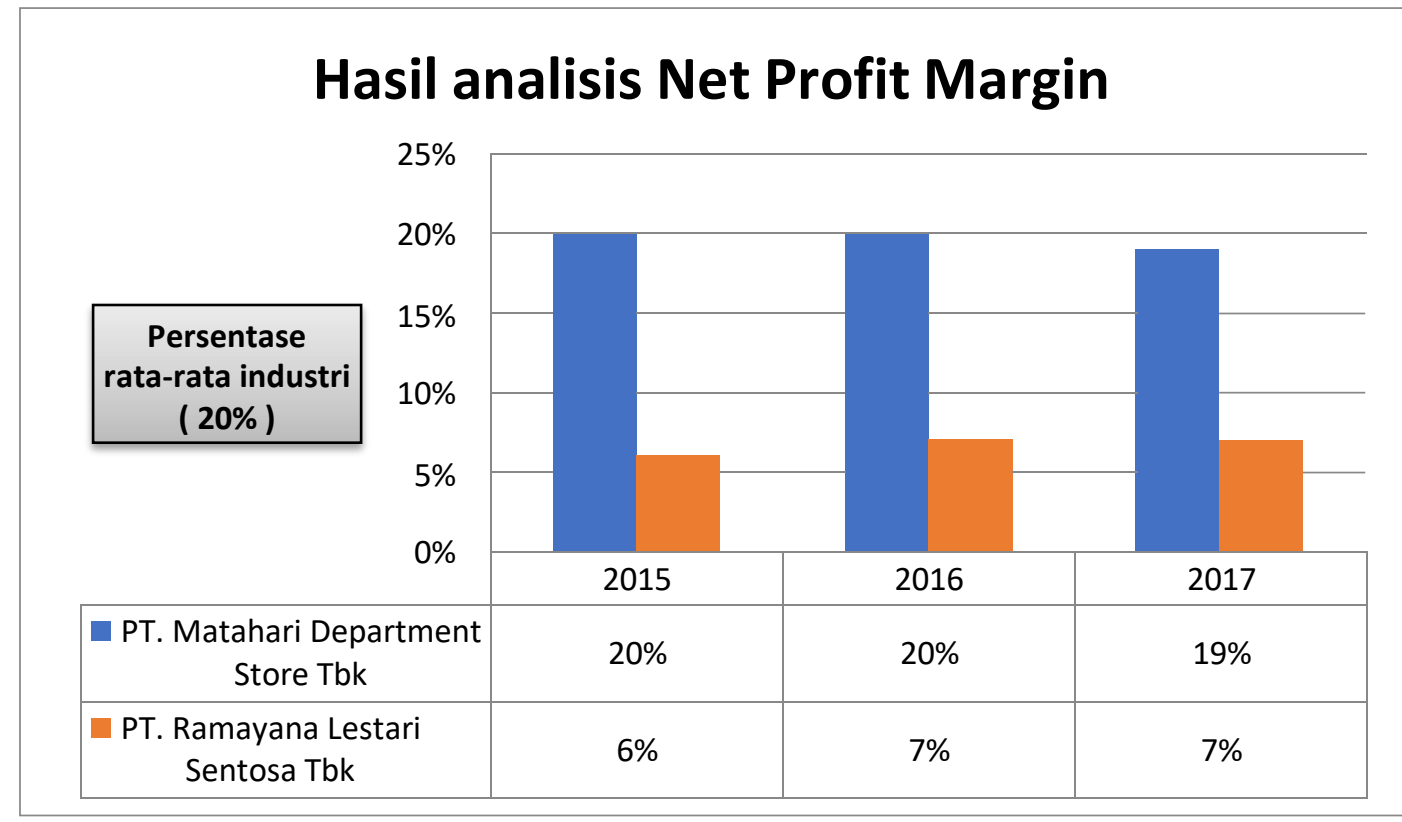

Berdasarkan analisis net profit margin, pada tahun 2015 hingga 2017 cenderung stabil yaitu senilai 20\% (2015), 20\% (2016) dan 19\% (2017). Walaupun terdapat penurunan yang tidak signifikan dari 2016 ke 2017, akan tetapi hal tersebut perlu diwaspadai mengingat nilai yang diperoleh pada tahun 2017 tersebut berada dibawah nilai rata-rata industri yang telah ditetapkan yaitu 20\%. Hal itu disebabkan 
oleh beberapa akun yang mengalami fluktuasi diantaranya Laba sesudah bunga dan pajak dan Penjualan pada periode tahun 2015, 2016 dan 2017 yaitu sebagai berikut

Tabel V.23 : Perubahan nilai persentase akun yang berkaitan dengan net profit margin pada periode tahun 2015-2017

\begin{tabular}{|c|c|c|c|c|c|c|}
\hline \multirow{2}{*}{$\begin{array}{l}\text { NAMA } \\
\text { AKUN }\end{array}$} & \multicolumn{3}{|c|}{$\begin{array}{c}\text { PT. MATAHARI DEPARTMENT } \\
\text { STORE TBK }\end{array}$} & \multicolumn{3}{|c|}{$\begin{array}{c}\text { PT. RAMAYANA LESTARI } \\
\text { SENTOSA TBK }\end{array}$} \\
\hline & 2015 & 2016 & 2017 & 2015 & 2016 & 2017 \\
\hline $\begin{array}{c}\text { EAIT } \\
\text { (Laba } \\
\text { Sesudah } \\
\text { Bunga \& } \\
\text { Pajak) }\end{array}$ & 1.780 .848 & $\begin{array}{l}2.019 .705 \\
(\uparrow 13,41 \%)\end{array}$ & $\begin{array}{l}1.907 .077 \\
(\downarrow 5,57 \%)\end{array}$ & 336.054 & $\begin{array}{c}408.479 \\
(\uparrow 21,55 \%)\end{array}$ & $\begin{array}{c}406.580 \\
(\downarrow 0,46 \%)\end{array}$ \\
\hline Penjualan & 9.006 .893 & $\begin{array}{l}9.897 .046 \\
(\uparrow 9,88 \%)\end{array}$ & $\begin{array}{l}10.023 .961 \\
(\uparrow 1,28 \%)\end{array}$ & 5.533 .004 & $\begin{array}{l}5.857 .037 \\
(\uparrow 5,85 \%)\end{array}$ & $\begin{array}{l}5.622 .728 \\
(\downarrow 4 \%)\end{array}$ \\
\hline
\end{tabular}

Gambar V.7 : Grafik komparasi hasil analisis return on investment

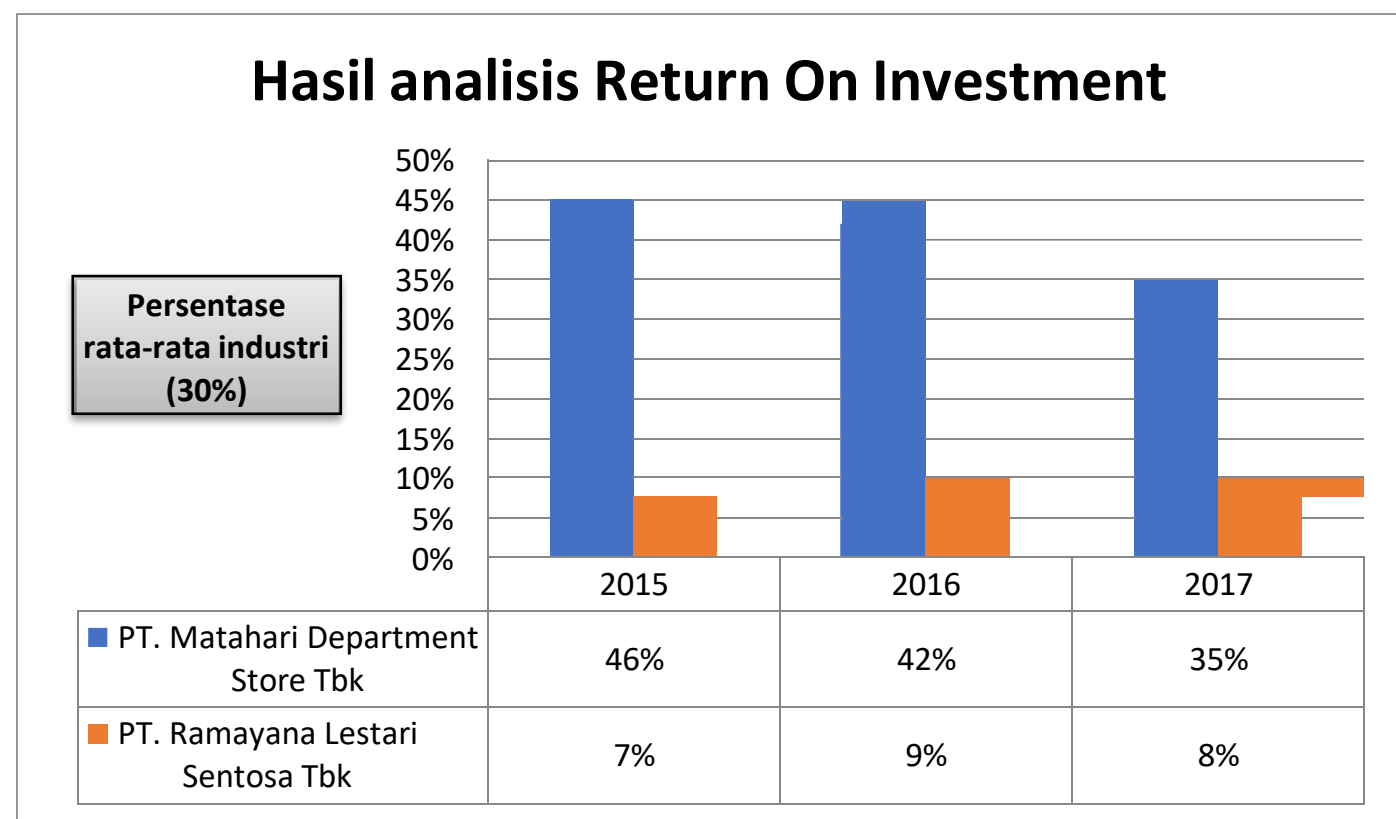

Berdasarkan analisis return on Investment, pada PT. Matahari Department Store Tbk mengalami penurunan persentase dari periode 2015 hingga 2017 yaitu senilai 46\% (2015), 42\% (2016) dan 35\% (2017). Walaupun begitu nilai yang diperoleh masih diatas rata-rata industri yaitu 30\%. Hal itu disebabkan oleh beberapa akun yang mengalami fluktuasi diantaranya Laba sesudah bunga dan 
pajak dan Total Aktiva pada periode tahun 2015, 2016 dan 2017 yaitu sebagai berikut :

Tabel V.24 : Perubahan nilai persentase akun yang berkaitan dengan return on investment pada periode tahun 2015-2017

\begin{tabular}{c|c|c|c|c|c|c}
\hline \multirow{2}{*}{$\begin{array}{c}\text { NAMA } \\
\text { AKUN }\end{array}$} & \multicolumn{3}{|c|}{ PT. MATAHARI DEPARTMENT } & \multicolumn{3}{|c}{ PT. RAMAYANA LESTARI } \\
\cline { 2 - 7 } STORE TBK & 2015 & 2016 & 2017 & 2015 & 2016 & 2017 \\
\hline $\begin{array}{c}\text { EAIT } \\
\text { (Laba } \\
\text { Sesudah } \\
\text { Bunga } \\
\text { \& } \\
\text { Pajak) }\end{array}$ & 1.780 .848 & $\begin{array}{c}2.019 .705 \\
(\uparrow 13,41 \%)\end{array}$ & $\begin{array}{c}1.907 .077 \\
(\downarrow 5,57 \%)\end{array}$ & 336.054 & $\begin{array}{c}408.479 \\
(\uparrow 21,55 \%)\end{array}$ & $\begin{array}{c}406.580 \\
(\downarrow 0,46 \%)\end{array}$ \\
\hline $\begin{array}{c}\text { Total } \\
\text { Aktiva } \\
\text { (Aset) }\end{array}$ & 3.889 .291 & $\begin{array}{c}4.858 .878 \\
(\uparrow 24,92 \%)\end{array}$ & $\begin{array}{c}(\uparrow .427 .426 \\
(\uparrow 11,70 \%)\end{array}$ & 4.574 .904 & $\begin{array}{c}4.647 .009 \\
(\uparrow 1,57 \%)\end{array}$ & $\begin{array}{l}4.891 .922 \\
(\uparrow 5,27 \%)\end{array}$ \\
\hline
\end{tabular}

Hal tersebut menunjukkan bahwa hasil (return) atas jumlah aktiva yang digunakan dalam perusahaan masih dalam kondisi yang baik walaupun terjadi penurunan secara berkala pada setiap tahunnya.

Sedangkan pada PT. Ramayana Lestari Sentosa Tbk tahun 2015 hingga 2017 cenderung fluktuatif yaitu senilai 7\% (2015), 9\% (2016) dan 8\% (2017). Berdasarkan nilai yang telah diperoleh tersebut memperlihatkan bahwa nilai yang diperoleh masih dibawah rata-rata industri. Sehingga hasil (return) atas jumlah aktiva yang digunakan dalam perusahaan tersebut dalam kondisi yang kurang baik. 
Gambar V.8 : Grafik komparasi hasil analisis return on equity

\section{Hasil analisis Return On Equity}

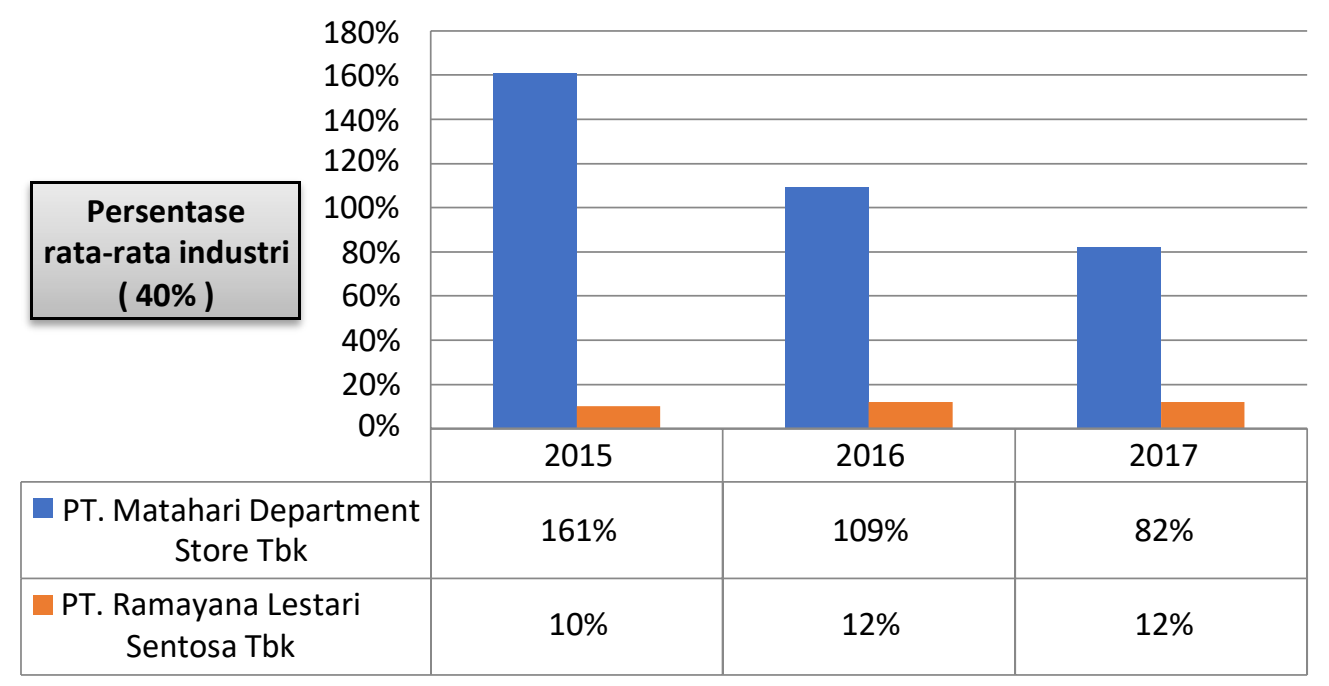

Berdasarkan analisis return on equity, PT. Matahari Department Store Tbk mengalami penurunan persentase dari periode tahun 2015 hingga 2017 yaitu senilai $161 \%$ (2015), 109\% (2016) dan 82\% (2017). Walaupun terjadi penurunan yang signifikan akan tetapi dari nilai yang diperoleh dari tiga periode tersebut memperlihatkan nilai diatas rata-rata industri yang telah ditetapkan yaitu $40 \%$. Hal itu disebabkan oleh beberapa akun yang mengalami fluktuasi diantaranya Laba sesudah bunga dan Total Ekuitas pada periode tahun 2015, 2016 dan 2017 yaitu sebagai berikut :

Tabel V.25 : Perubahan nilai persentase akun yang berkaitan dengan return on equity pada periode tahun 2015-2017

\begin{tabular}{c|c|c|c|c|c|c}
\hline \multirow{2}{*}{$\begin{array}{c}\text { NAMA } \\
\text { AKUN }\end{array}$} & \multicolumn{3}{|c|}{ PT. MATAHARI DEPARTMENT } & \multicolumn{3}{c}{ PT. RAMAYANA LESTARI } \\
\cline { 2 - 7 } STORE TBK & 2015 & 2016 & 2017 & 2015 & 2016 & 2017 \\
\hline $\begin{array}{c}\text { EAIT } \\
\text { (Laba }\end{array}$ & & & & & & \\
$\begin{array}{c}\text { Sesudah } \\
\text { Bunga } \\
\&\end{array}$ & 1.780 .848 & $\begin{array}{c}2.019 .705 \\
(\uparrow 13,41 \%)\end{array}$ & $\begin{array}{c}1.907 .077 \\
(\downarrow 5,57 \%)\end{array}$ & 336.054 & $\begin{array}{c}408.479 \\
(\uparrow 21,55 \%)\end{array}$ & $\begin{array}{c}406.580 \\
(\downarrow 0,46 \%)\end{array}$ \\
$\begin{array}{c}\text { Pajak) } \\
\text { Total }\end{array}$ & 1.106 .167 & $\begin{array}{c}1.855 .243 \\
(\uparrow 67,71 \%)\end{array}$ & $\begin{array}{c}2.327 .985 \\
(\uparrow 25,48 \%)\end{array}$ & 3.333 .804 & 3.337 .399 & 3.494 .345 \\
Ekuitas & & & & & $(\uparrow 0,10 \%)$ & $(\uparrow 4,70 \%)$ \\
\hline
\end{tabular}


PT. Ramayana Lestari Sentosa Tbk menunjukkan peningkatan yang tidak terlalu signifikan dari tahun 2015 hingga 2017 yaitu senilai 10\% (2015), 12\% (2016) dan 12\% (2017). Walaupun terjadi peningkatan namun nilai yang diperoleh masih dibawah rata-rata industri yang telah ditetapkan berdasarkan kondisi tersebut menunjukkan bahwa kemampuan manajemen untuk memperoleh ROE masih kurang baik.

Berdasarkan hasil analisis rasio profitabilitas yang telah dilakukan yaitu berupa net profit margin, return on Investment dan return on equity pada PT. Matahari Department Store Tbk dan PT. Ramayana Lestari Sentosa Tbk pada periode tahun 2015 hingga 2017. Hal tersebut menunjukkan bahwa rasio profitabilitas yang dihasilkan PT. Matahari Department Store Tbk cenderung mengalami penurunan walaupun begitu nilai yang dihasilkan masih berada diatas rata-rata. Sehingga berdasarkan analisis tersebut menunjukkan bahwa PT. Matahari Department Store Tbk masih mampu dalam mengelola aktiva dan ekuitas yang dimiliki perusahaan serta memperoleh margin laba bersih.

Sedangkan rasio profitabilitas PT. Ramayana Lestari Sentosa Tbk cenderung mengalami peningkatan walaupun berdasarkan hasil yang diperoleh masih berada dibawah rata-rata. Sehingga menunjukkan bahwa PT. Ramayana Lestari Sentosa Tbk kurang mampu dalam mengelola aktiva dan ekuitas yang dimiliki perusahaan serta memperoleh margin laba bersih.

Dari data hasil analisis yang telah dikemukakan maka dapat disimpulkan bahwa rasio likuiditas PT. Ramayana Lestari Sentosa Tbk lebih baik dibandingkan dengan PT. Matahari Department Store Tbk, Sedangkan untuk rasio profitabilitas menunjukkan bahwa PT. Matahari Department Store Tbk cenderung lebih baik daripada PT. Ramayana Lestari Sentosa Tbk pada periode 2015 hingga 2017. Sehingga pernyataan penelitian yang diajukan tidak dapat diterima.

\section{Kesimpulan}

Berdasarkan hasil penelitian untuk penilaian kinerja dengan menggunakan analisis rasio keuangan yaitu analisis rasio likuiditas dan rasio profitabilitas pada perusahaan PT. Matahari Department Store Tbk dan PT. Ramayana Lestari Sentosa Tbk yang merupakan sampel dalam penelitian, maka kesimpulan dalam penelitian ini adalah :

1. Kinerja Perusahaan PT. Matahari Department Store Tbk berdasarkan hasil perhitungan analisis rasio likuiditas pada periode tahun 2015 hingga 2017 menunjukkan hasil yang kurang baik walaupun terjadi peningkatan, akan tetapi rasio lancar dan rasio cepat menunjukkan hasil dibawah rata-rata. Sehingga berdasarkan analisis tersebut menunjukkan bahwa kurangnya kemampuan perusahaan dalam memenuhi kewajiban jangka pendeknya. Sedangkan dari segi rasio profitabilitas yang dihasilkan PT. Matahari Department Store Tbk 
cenderung mengalami penurunan walaupun begitu nilai yang dihasilkan masih berada diatas rata-rata. Sehingga berdasarkan analisis tersebut menunjukkan bahwa PT. Matahari Department Store Tbk Masih mampu dalam mengelola aktiva dan ekuitas yang dimiliki perusahaan serta memperoleh margin laba bersih.

2. Kinerja Perusahaan PT. Ramayana Lestari Sentosa Tbk berdasarkan hasil perhitungan analisis rasio likuiditas yang dihasilkan PT. Ramayana Lestari Sentosa Tbk dominan lebih baik, walaupun terdapat 1 aspek yang berada dibawah rata-rata yaitu rasio perputaran kas akan tetapi secara garis besar rasio likuiditas menunjukkan bahwa PT. Ramayana Lestari Sentosa Tbk memiliki kemampuan untuk memenuhi kewajiban jangka pendeknya. Sedangkan rasio profitabilitas PT. Ramayana Lestari Sentosa Tbk cenderung mengalami peningkatan walaupun berdasarkan hasil yang diperoleh masih berada dibawah rata-rata. Sehingga menunjukkan bahwa PT. Ramayana Lestari Sentosa Tbk kurang mampu dalam mengelola aktiva dan ekuitas yang dimiliki perusahaan serta memperoleh laba bersih.

3. Berdasarkan hasil akhir analisis menunjukkan bahwa rasio likuiditas PT. Ramayana Lestari Sentosa Tbk cenderung lebih baik dibandingkan PT. Matahari Department Store Tbk, sedangkan dari rasio profitabilitas menunjukkan PT. Matahari Department Store Tbk Cenderung lebih baik daripada PT. Ramayana Lestari Sentosa Tbk pada periode tahun 2015 hingga 2017. 


\section{DAFTAR PUSTAKA}

Hery, Akuntansi Keuangan Menengah, 2013, Cetakan Pertama, CAPS, Yogyakarta.

Islahuzzaman, Istilah-istilah Akuntansi \& Auditing, 2012, PT Bumi Aksara, Jakarta.

Kasmir, Analisis Laporan Keuangan, 2012, Edisi Revisi, Cetakan Kesembilan, PT Raja Grafindo Persada, Jakarta.

Monika Indah R., Analisis Kinerja Keuangan PT. Matahari Department Store Tbk berdasarkan Rasio Likuiditas, Solvabilitas, Provitabilitas dan Aktivitas pada tahun 2010-2014, Skripsi (D3), 2016, Akuntansi, Fakultas Ekonomi dan Bisnis, Universitas Sebelas Maret, Surakarta.

Nitiseminto, Alex S., Pembelanjaan Perusahaan, 2000, Edisi Revisi, Penerbit Ghalia Indonesia, Jakarta.

Riyanto, Bambang, Dasar-dasar Pembelanjaan Perusahaan, 1995, Edisi Keempat, Cetakan Keempat Belas, Yayasan Penerbit Fakultas Ekonomi, Universitas Gadjah Mada, Yogyakarta.

S. Munawir, Analisis Laporan Keuangan, 2007, Edisi Keempat, Cetakan Keempat Belas, Liberty, Yogyakarta.

Santoso, Iman, Akuntansi Keuangan Menengah (Intermediate Accounting) Buku Dua, 2009, Cetakan Pertama, PT Refika Aditama, Bandung.

Sawir, Agnes, Analisis Kinerja Keuangan dan Perencanaan Keuangan Perusahaan, 2001, PT Gramedia Pustaka Utama, Jakarta.

Sri Rahayu, Analisis Tingkat Rentabilitas, Likwiditas dan Solvabilitas pada UD. SANGKUANG di Samarinda, Skripsi (S1), 2014, Manajemen, Fakultas Ekonomi, Universitas Widya Gama Mahakam, Samarinda.

Syamsuddin, Lukman, Manajemen Keuangan Perusahaan, 2004, Edisi Terbaru, Cetakan Kedelapan, PT Raja Garfindo Persada, Jakarta.

\section{Http://www.idx.co.id}

